\title{
Lack and accumulation of boron in the leaves after foliar spraying in cabbage and cauliflower plants
}

\section{Deficiência e acúmulo de boro nas folhas após a pulverização foliar das plantas de repolho e de couve-flor}

\author{
Adriana Ursulino ALVES ${ }^{\text {; }}$ Renato de Mello PRADO ${ }^{2}$; Ancélio Ricardo de Oliveira GONDIM ${ }^{3}$; \\ Marcus André Ribeiro CORREIA ${ }^{4}$; Arthur Bernardes CECÍLIO FILHO 5 \\ ${ }^{1}$ Doutora em Produção Vegetal - Agronomia, Universidade Federal do Piauí, Câmpus Professora Cinobelina Elvas, \\ adrianaursulino@ufpi.edu.br \\ 2 Doutor em Produção Vegetal - Agronomia, Universidade Estadual Paulista "Júlio de Mesquita Filho" Câmpus de Jaboticabal, \\ rm.prado@unesp.br \\ ${ }^{3}$ Doutor em Produção Vegetal - Agronomia, Universidade Federal de Campina Grande, Câmpus Pombal, \\ anceliogondim@hotmail.com \\ ${ }^{4}$ Autor para correspondência" Doutor em Produção Vegetal - Agronomia, Instituto Federal do Tocantins, Câmpus Colinas do \\ Tocantins, correia@ifto.edu.br \\ ${ }^{5}$ Doutor em Fitotecnia - Agronomia, Universidade Estadual Paulista "Júlio de Mesquita Filho" Câmpus de Jaboticabal, \\ arthur.cecilio@unesp.br
}

\section{Recebido em: 01-04-2019; Aceito em: 02-11-2019}

\section{Abstract}

Boron deficiency causes biological damage in brassicas according to the growth phase. In this condition, foliar spraying of B causes immediate effects of nutrient accumulation on leaves that may vary in brassicas but are not known. Therefore, the nutritional deficiency as well as the accumulation of B in the leaves over 30 days after their spraying on cabbage and cauliflower plants were evaluated. Were, two experiments were carried out to evaluate the lack of $B$ in the nutritive solution on the nutrition, growth and production of the two brassicas. The other experiments evaluated the dry mass and B leaf content at 0.12 (3 h); 0.25 (6 h); 0.5 (12 h) 1, 5, 15 and 30 days after leaf spraying of the micronutrient and also in the plants that did not receive $B$ in the two brassicas. The effect of the lack of boron was evident in the final growth stage of the plants, causing a decrease in productivity, cabbage was more sensitive to nutrient deficiency than cauliflower, however. Boron is slowly accumulated by the leaves of the 'Astrus' cabbage, absorbing 50\% of the applied B, about 15 days after its application and 'Verona' cauliflower, at three days and 12 hours after its application.

Additional keywords: brassicas; micronutrient; nutrition.

\section{Resumo}

A deficiência de $\mathrm{B}$ causa prejuízo biológico nas brássicas dependendo da fase de crescimento. Nesta condição, a pulverização foliar de B causa efeitos imediatos do acúmulo do nutriente nas folhas que pode variar nas brassicas, mas não são conhecidos. Diante disso, avaliaram a deficiência nutricional e também o acúmulo do B nas folhas durante 30 dias após a sua pulverização nas plantas de repolho e couve-flor. Foram desenvolvidos dois experimentos para avaliar a omissão de B na solução nutritiva na nutrição, crescimento e na produção das duas brássicas. Em outros experimentos foram avaliados a massa seca e o teor de B nas folhas aos 0,12 (3 h), 0,25(6 h), 0,5 (12 h) 1, 5, 15 e 30 dias após a pulverização foliar do micronutriente e também nas plantas que não receberam o $\mathrm{B}$ nas duas brassicas. $\mathrm{O}$ efeito da omissão de boro ficou evidente na fase final de crescimento das hortaliças, causando diminuição na produtividade, mas repolho foi mais sensível a deficiência do nutriente em relação a couve-flor. O B é acumulado lentamente pelas folhas do repolho 'Astrus', absorvendo 50\% do $B$ aplicado, próximo de 15 dias após sua aplicação e na couve-flor 'Verona' aos três dias e 12 horas após sua aplicação.

Palavras-chave adicionais: brassicas; micronutriente; nutrição.

\section{Introduction}

Brassica vegetables present high levels of health-promoting nutrients and phytochemicals (that is, phenolics, glucosinolates, vitamins and minerals). Epidemiological studies indicate that the raise in the consumption of Brassicas is strongly associated with a reduced risk of degenerative diseases, cancer, cardiovascular diseases and immunological dysfunction (Francisco et al., 2017).

The adequate development and production of brassicas depends very much on boron nutrition (Prado, 2008) since this element is important for meristematic tissues as it increments cell division and 
'Verona' cultivated in nutrient solution.

Sowing of the brassica cabbage and the cauliflower were carried out in phenolic foam. On day 10 after emergence, cabbage and cauliflower seedlings were transplanted to $5-\mathrm{cm}$ wide polypropylene channels with nutrient solution Hoagland \& Arnon (1950), with no boron and with $25 \%$ of nutrient concentration, in a nutrient film technique (NFT) hydroponic system, with recirculation of the nutrient solution.

The cabbage and cauliflower seedlings remained in this condition for nine days, when the seedlings were transplanted to plastic containers with a capacity of $5 \mathrm{~L}$ (1 plant per pot), containing complete nutrient solution and the other seedlings in solution without $\mathrm{B}$. Before the transplanting, the root system and the phenolic foam were washed in distilled water. The plants were spaced at $0.80 \times 0.35 \mathrm{~m}$ for the cabbage and $1.00 \times 0.50 \mathrm{~m}$ for the cauliflower on the rows and between rows, respectively.

A randomized complete block design was used in split-plot in time with four replications. In the plots, Hoagland \& Arnon (1950) nutrient solutions (1950) were evaluated with $0.5 \mathrm{mg} \mathrm{L}^{-1}$ and without $B$ and in the subplots, the growth phases differentiation, being related to sugar transport, lignification, carbohydrate metabolism, RNA metabolism, respiration, indole acetic acid metabolism (IAA) and metabolism of phenol and ascorbate (Cakmak \& Römheld, 1997).

The small crop production is attributable to the reduction in the micronutrient contents in plant tissues and important vegetative variables such as stem diameter, leaf area and root and dry mass accumulation in leaves and roots that can vary according to the growing phase of the crop and with the brassica under study. However, the differences in these biological losses resulting from $B$ deficiency are little known in the new cabbage and cauliflower cultivars.

Fertilization practices, which can be carried out through soil or leaves, are important to prevent B deficiency in the plants. Overall, the practice of foliar fertilization has developed rapidly in the world in the last years and it is assumed that it is carried out to correct deficiencies as well as to supplement soil fertilization over the complete crop cycle or in the reproductive stage of the plants (Marschner, 1995). Brassicas have a high boron demand so the practice of the foliar sprays is common (Kerbauy, 2004). Foliar fertilization using $B$ increases the vegetative variables and brassica production (Prasad \& Yadav, 2003; Ningawale et al., 2016). Absorption of nutrients through the leaf surface is restricted due to the presence of the cuticle and the wax layer on the outer walls of epidermal cells. In addition, rate of nutrient absorption depends mainly on the thickness of the cuticle and the wax layer (Kerbauy, 2004). The leaves of cabbage and cauliflower have a thick layer of epicuticular wax especially in the occurrence of boron deficiency (Pandey \& Verma, 2017). Therefore, the accumulation of $B$ in leaves immediately after foliar spraying of the nutrient may be very slow, according to the brassica, although this information is not known.

As a result, the first hypothesis that the brassica response to moderate $B$ deficiency may cause distinct effects on the vegetative variables during its growth is raised. Moreover, it is likely that differences may occur in the rate of $B$ accumulation in the leaves among brassicas just after the nutrient spraying and its beneficial reflections on the accumulation of dry mass.

Therefore, this study evaluated the nutritional deficiency as well as the accumulation of $B$ in the leaves over 30 days after its spraying on cabbage and cauliflower plants.

\section{Materials and methods}

The four experiments were carried out at UNESP, Jaboticabal campus, using 'Astrus Plus' cabbage plants and 'Verona 184' hybrid cauliflower. Experiments I and II were developed to evaluate the lack of $B$ in the nutrient solution in the two brassicas and the experiments III and IV were carried out to evaluate the immediate effects of leaf boron spraying in both brassicas.

\section{Experiment I and II}

These two experiments evaluated the effects of the lack of boron in the growth and nutrition of cabbage plants 'Astrus' and cauliflower (sampling times) were evaluated for dry mass accumulation and growth. Cabbage: first stage (0-25 days after transplanting, DAT), characterized by slow growth, small accumulation of dry mass in relation to the total accumulated at the end of the cycle; second phase (26-50 DAT) characterized by rapid increase of dry mass in the aerial part; and third stage (51-84 DAT) characterized by the formation of the head (edible part). Cauliflower: first stage (0-30 DAT) characterized by slow growth, small accumulation of dry mass in relation to the total accumulated total at the end of the cycle; second phase (31-55 DAT) characterized by rapid increase of dry mass in the aerial part; and third stage (56-95 DAT) characterized by large accumulation of dry mass in the aerial part and inflorescence formation.

During the execution of the experiment, the $\mathrm{pH}$ value of the nutrient solution was adjusted to $5.5 \pm 0.5$. When the electrical conductivity (EC) reached approximately $60 \%$ of the initial value, the nutrient solution was replaced by maintaining the EC $\left(1.5 \mathrm{dS} \mathrm{m}^{-1}\right)$ and every 15 days, it was renewed. The nutrient solution was constantly aerated with compressed air.

At each stage of development (sampling times), cabbage and cauliflower plants were divided into root, stem, leaf and edible part (head or inflorescence). The total $\mathrm{B}$ content in the different organs was determined by the azomethine- $\mathrm{H}$ method in extract obtained by dry digestion (Tedesco et al., 1995).

Plant height, number of leaves, stem diameter, 
leaf area, root dry mass, leaf dry mass, stem dry mass, and fresh and dry mass of the edible part were evaluated at the different stages of brassica growth. The plant materials were washed (detergent solution at $3 \mathrm{~mL} \mathrm{~L}^{-1}$, running water, $0.1 \mathrm{~mol} \mathrm{~L}^{-1} \mathrm{HCl}$ solution and distilled water, respectively) according to methodology of Peryea (2005) and dried in forced air circulation oven, at $65-68^{\circ} \mathrm{C}$. By using the results of the dry mass in the different organs of the plant and boron content, the micronutrient accumulation was calculated.

The results were submitted to analysis of variance ( $F$ test) by the SAEG software (2000). When they were significant, the averages were compared by the Tukey test at the 5\% probability level.

\section{Experiment III and IV}

The immediate effects of leaf boron spraying on 'Astrus' cabbage and 'Verona' cauliflower were evaluated in these experiments. Seeds of the vegetables were grown in phenolic foam. After seven days of emergence, the cabbage and cauliflower seedlings were grown as indicated in experiments I and II.

The cabbage and cauliflower seedlings remained in this condition for 13 days, when one plant was transplanted in plastic pot with a capacity of $10 \mathrm{dm}^{3}$, filled with washed sand. The nutrient solution of Hoagland \& Arnon (1950) was used.

A randomized complete block design was used. The treatments were distributed in split-plots in time, with 14 treatments and ten replications. In the plots were evaluated two doses of $B, 0$ and $0.240 \mathrm{~g} \mathrm{~L}^{-1}$ for the cabbage and 0 and $0.340 \mathrm{~g} \mathrm{~L}^{-1} \mathrm{~B}$ for cauliflower were evaluated. As boron source, boric acid was used, with $17 \% \mathrm{~B}$. In the sub-plots, leaves were harvested seven times after $B$ solution were, as follows: 0.12 (3 h); $0.25(6$ h); 0.5 (12 h) 1; 5; 15 and 30 days after application.

Foliar application of boron was carried out at 23 days after transplanting (DAT) for cabbage and at 20 DAT for cauliflower, using a manual spray of one liter of capacity. The amount of solution applied was defined by a blank test (water solution and adhesive spreader), providing $8 \mathrm{~mL}$ per cabbage plant and $7 \mathrm{~mL}$ per plant of the solution of boric acid for cauliflower. The upper portion of the pots was properly protected, so the solution applied via leaves did not contaminate the substrate and nutrient could have been absorbed by the roots. During the experiment, sprayings were performed using Decis ${ }^{\circledR}$ (Deltrametrin, at a concentration of $0.04 \mathrm{~mL}$ per $\mathrm{L}$ ).

The leaves were harvested at the times after leaf boron spraying, which were, as follows: $0.12(3 \mathrm{~h})$; 0.25 (6 h); 0.5 (12 h) $1 ; 5 ; 15$ and 30 days after application. Leaf and root samples were washed and dried as previously described. Then, dry mass of the root and the leaves of the plant were determined. In the leaf samples, boron content was determined according to the methodology indicated in the previous experiment. In addition, by using data of B content and dry mass of the leaves, the accumulation of the micronutrient was calculated.

\section{Results and discussion}

\section{Experiments I and II}

\section{Cabbage \\ Effect of the treatments on nutrition}

It was observed that the cultivation of cabbage plants in the nutrient solution with omission of $B$ was effective in reducing $B$ content in the leaves, in the edible part and its accumulation in all organs of the plant and in the whole plant (Table 1). Therefore, the highest levels of boron were found in the leaves of the plants grown in nutrient solution with boron in the three phenological stages, presenting increases by $163 \%$, $341 \%$ and $570 \%$ in the first, second and third collection, respectively, in relation to the nutrient solution with omission of boron. A similar fact occurred with accumulation of this nutrient in the whole plant, promoting the increase of the boron accumulation in the presence of the micronutrient in relation to its absence in the nutrient solution of $190 \%, 306 \%$ and $513 \%$ in the three growth phases, respectively. The content and accumulation of boron in the edible part also presented the highest values in the nutrient solution with boron, with increases of $125 \%$ and $350 \%$, respectively, in comparison to the nutrient solution without boron. The accumulation of boron achieved in the cabbage plants of the solution without boron means that it may contain traces of the nutrient in the fertilizers used in the nutrient solution without boron and also in the seed.

\section{Treatment effects on growth and development}

Stem diameter, leaf area and root dry mass were reduced in plants grown in the nutrient solution with the omission of $\mathrm{B}$ only in the third growth stage (Table 2). It was observed that the biological damage caused in these variables because of the micronutrient deficiency only occurred when the content of $B$ in the leaves was less than or equal to $17 \mathrm{~g} \mathrm{~kg}^{-1}$.

Alam (2007) also observed that B deficiency reduced the size of cabbage leaves.

For the dry mass of the stem, a difference was found between the nutritive solutions in the second and third growth phases. However, the omission of B in the nutrient solution decreased the dry mass of leaves and the whole plant in the three growth stages (Table 2). Therefore, $\mathrm{B}$ contents in the leaves equal to or less than $27 \mathrm{~g} \mathrm{~kg}^{-1}$ resulted in low dry mass production of the plant. However, B contents in the leaves equal to 71 to $114 \mathrm{~g} \mathrm{~kg}^{-1}$ during its growth promoted greater mass production of the cabbage plant.

Because of the losses caused by B deficiency in the vegetative variables, the supply of this element in the nutrient solution promoted increments of fresh and dry mass of the edible part in the plant, reaching increments of $85 \%$ and $103 \%$, respectively, in comparison to the results of the nutrient solution without boron. The larger production of plants is due to the fact that the supply of $B$ in the nutrient solution increased its uptake during the three growth stages (Table 1) 
Table 1 - Boron content and accumulation in different parts of the 'Astrus' cabbage plant, as a function of nutrient solution with and without boron and at different growth stages.

\begin{tabular}{lccc}
\hline Treatments & First $^{(1)}$ & $\begin{array}{c}\text { Growth phases } \\
\text { Second }\end{array}$ & Third \\
\hline & & $\begin{array}{c}\text { Boron content }\left(\mathrm{mg} \mathrm{kg}^{-1}\right) \\
\text { Leaf }\end{array}$ & \\
Solution with boron & $71 \mathrm{Ac}$ & $97 \mathrm{Ab}$ & $114 \mathrm{Aa}$ \\
Solution without boron & $27 \mathrm{Ba}$ & $22 \mathrm{Bab}$ & $17 \mathrm{Bb}$ \\
& $-(2)$ & - & $45 \mathrm{~A}$ \\
Solution with boron & - & - & $20 \mathrm{~B}$ \\
Solution without boron & & Boron accumulation (mg per plant) & \\
& & Leaf & \\
Solution with boron & $0.50 \mathrm{Ac}$ & $1.87 \mathrm{Ab}$ & $6.12 \mathrm{Aa}$ \\
Solution without boron & $0.15 \mathrm{Bb}$ & $0.40 \mathrm{Bb}$ & $0.79 \mathrm{Ba}$ \\
& & Stem & $0.39 \mathrm{Aa}$ \\
Solution with boron & $0.04 \mathrm{Ac}$ & $0.14 \mathrm{Ab}$ & $0.20 \mathrm{Ba}$ \\
Solution without boron & $0.03 \mathrm{Bc}$ & $0.08 \mathrm{Bb}$ & $0.09 \mathrm{Aa}$ \\
Solution with boron & & Root & $0.05 \mathrm{Ba}$ \\
Solution without boron & $0.03 \mathrm{Ac}$ & $0.06 \mathrm{Ab}$ & \\
& $0.02 \mathrm{Bc}$ & $0.04 \mathrm{Bb}$ & $0.63 \mathrm{~A}$ \\
Solution with boron & - & Edible part & $0.14 \mathrm{~B}$ \\
Solution without boron & - & - & $7.23 \mathrm{Aa}$ \\
& & - & $1.18 \mathrm{Ba}$ \\
Solution with boron & $0.58 \mathrm{Ac}$ & Whole plant & $2.07 \mathrm{Ab}$ \\
Solution without boron & $0.20 \mathrm{Bc}$ & $0.51 \mathrm{Bb}$ & \\
\hline
\end{tabular}

Mean followed by the same capital letter in the column and lowercase letter in the row do not differ at $5 \%$ probability by the Tukey's test. ${ }^{(1)}$ Cabbage growth stages at 25 (first), 50 (second) and 84 (third) days after transplantation; ${ }^{(2)}$ Variable not evaluated due to absence of organ in the plant.

Table 2 - Root diameter, leaf area, root dry mass, stem dry mass and leaf dry mass, fresh and dry mass of the edible part and dry mass of the whole 'Astrus' cabbage plant, as a function of nutrient solution with and without boron and at different growth stages

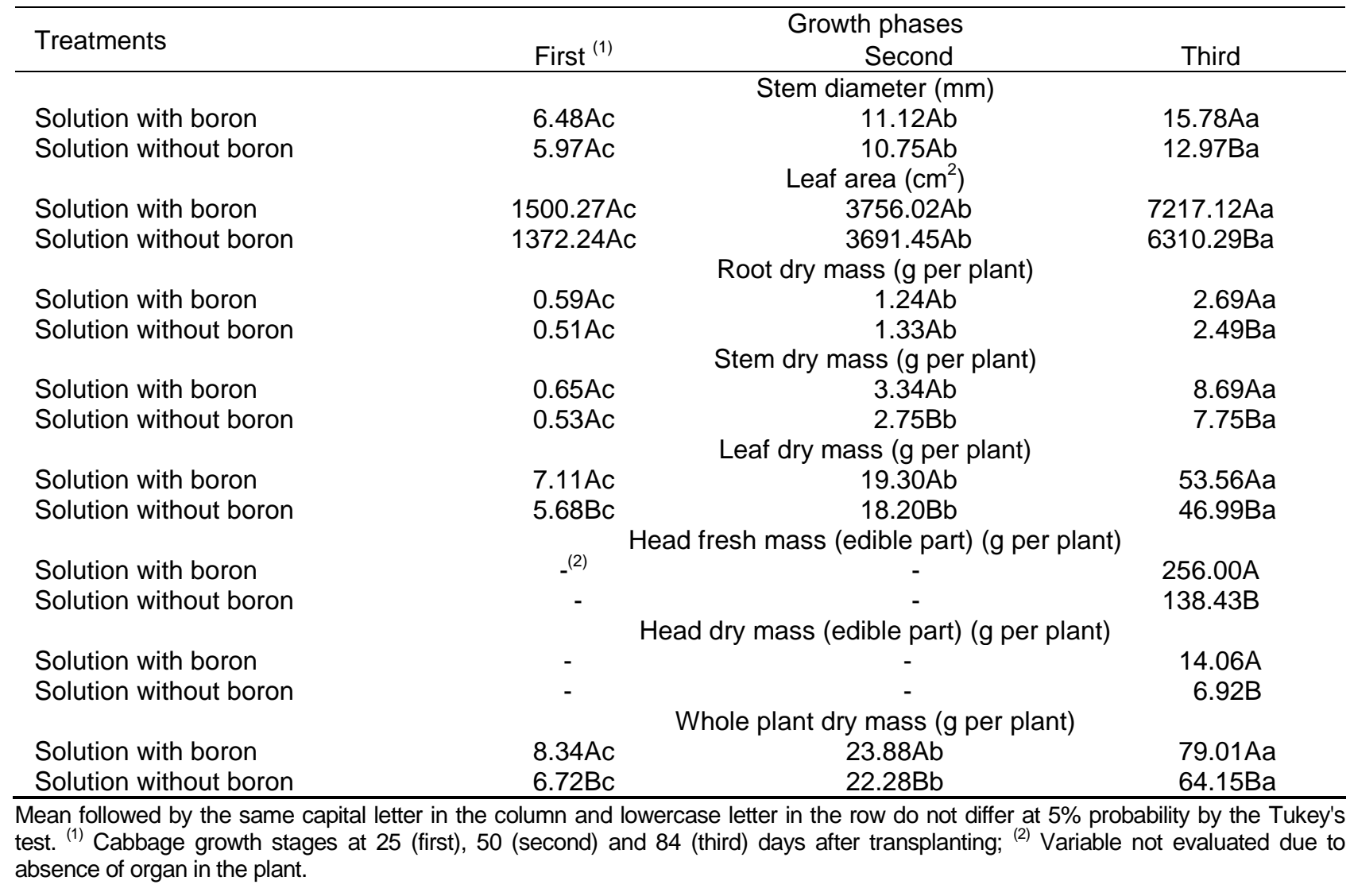


The importance of $B$ in the production of cabbage was evidenced by other authors (Pizetta et al., 2005; Silva et al., 2012). Micronutrient-deficient cabbage plants depreciate the nutritional value of the edible part (head) as they presented low B content $\left(20 \mathrm{~g} \mathrm{~kg}^{-1}\right)$, a value well lower than those of the plants under sufficiency $\left(45 \mathrm{~g} \mathrm{~kg}^{-1}\right)$ that presented high production. As the daily recommendation of boron for human consumption is $10 \mathrm{mg}$ (Naghii et al., 2011), this shows that even with the low content of $20 \mathrm{~g} \mathrm{~kg}^{-1}$, it is possible to attend the nutritional requirement.

\section{Cauliflower \\ Effect of the treatments in the nutrition}

Regarding the cauliflower, the highest levels of boron were found in the leaves of the plants grown with boron solution in the three growth phases, reaching increments of $186 \%, 332 \%$ and $833 \%$, respectively, in relation to the solution without boron. An increment was observed in B content in the root reaching $14 \%, 11 \%$ and $100 \%$ in the first, second and third growth stages, respectively, in the plants grown in the nutrient solution with presence of the micronutrient in relation to its absence (Table 3 ).

Table 3 - Boron content and accumulation in different parts of "Verona' cauliflower as a function of the nutritive solution with and without boron at different growth stages.

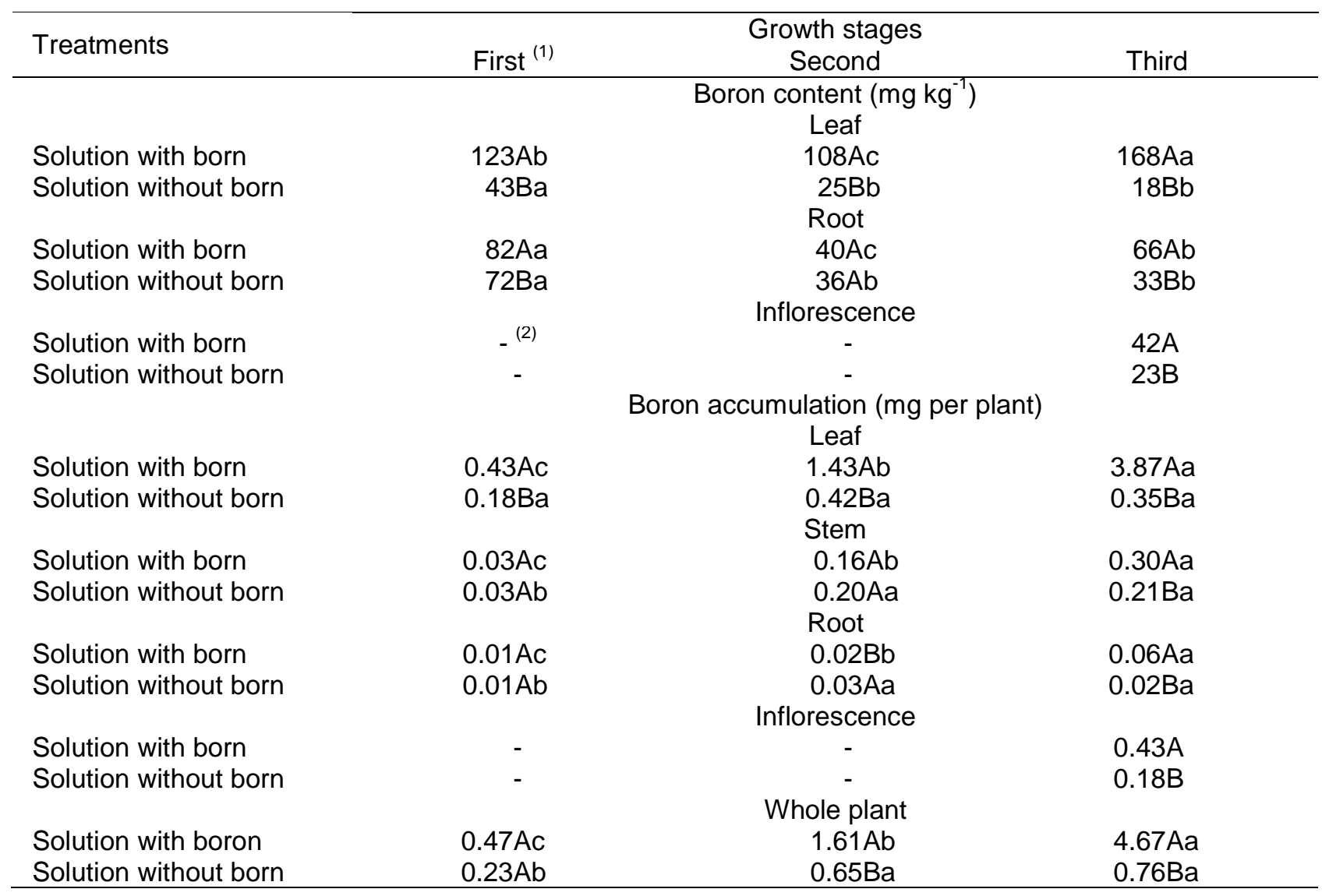

Mean followed by the same capital letter in the column and lowercase letter in the row do not differ at $5 \%$ probability by the Tukey's test. ${ }^{(1)}$ Cauliflower growth stages at 30 (first), 55 (second) and 95 (third) days after transplanting; ${ }^{\left({ }^{2}\right)}$ Variable not evaluated due to absence of organ in the plant.

In plants grown in nutrient solution with boron, greater accumulations of the micronutrient were found in the leaves and in the whole plant. The increment of boron accumulation in the whole plant in nutrient solution with presence of boron in relation to its absence in the nutrient solution were $104 \%, 148 \%$ and $514 \%$ in the three growing phases, respectively. The content and accumulation of boron in the inflorescence also presented higher values in the nutrient solution with boron, reaching increases of $83 \%$ and $139 \%$, respectively, in comparison to the nutrient solution without boron. The highest increase in boron accumulation in the whole cauliflower plant was obtained in the nutrient solution with boron in the third growth phase, in com- parison to the nutrient solution without the micronutrient.

\section{Effect of the treatments on growth and develop- ment}

The lack of $B$ in the nutrient solution decreased the leaf area and dry mass of the cauliflower root only in the third growth phase (Table 4). The effect of B deficiency on the nutrient solution decreased the production of the plants from the fresh and dry mass of the inflorescence, compared to the control plants, which received $B$ in the nutrient solution (Table 4). 
Table 4 - Leaf area, root dry mass and fresh and dry mass of the inflorescence, in 'Verona' cauliflower plants, as a function of nutrient solution with and without boron and at different growth stages

\begin{tabular}{lccc}
\hline Treatments & \multicolumn{3}{c}{ Growth stage } \\
& First ${ }^{(1)}$ & Second & Third \\
\hline & & Leaf area $\left(\mathrm{cm}^{2}\right)$ \\
Solution with boron & $638.99 \mathrm{Ac}$ & $1830.23 \mathrm{Ab}$ & $4467.50 \mathrm{Aa}$ \\
Solution without boron & $671.08 \mathrm{Ac}$ & $2367.23 \mathrm{Ab}$ & $3825.09 \mathrm{Ba}$ \\
& & Root dry mass (g per plant) \\
Solution with boron & $0.06 \mathrm{Ac}$ & $0.77 \mathrm{Ab}$ & $0.98 \mathrm{Aa}$ \\
Solution without boron & $0.12 \mathrm{Ab}$ & $0.8 \mathrm{Aa}$ & $0.72 \mathrm{Ba}$ \\
& - & Inflorescent fresh 7 mass (g per plant) \\
Solution with boron & $-(2)$ & - & $132.75 \mathrm{~A}$ \\
Solution without boron & - & - & $95.31 \mathrm{~B}$ \\
& - & Inflorescence dry mass (g per plant) & \\
Solution with boron & - & - & $10.23 \mathrm{~A}$ \\
Solution without boron & - & - & $7.61 \mathrm{~B}$ \\
\hline
\end{tabular}

Mean followed by the same capital letter in the column and lowercase letter in the row do not differ at $5 \%$ probability by the Tukey's test. ${ }^{(1)}$ Cauliflower growth stages at 30 (first), 55 (second) and 95 (third) days after transplanting; ${ }^{(2)}$ Variable not evaluated due to absence of organ in the plant.

Leaf contents of $B$ equal to or less than $43 \mathrm{~g} \mathrm{~kg}^{-1}$ resulted in low plant production. However, $\mathrm{B}$ contents in leaves equal to 108 to $168 \mathrm{~g} \mathrm{~kg}^{-1}$ during its growth promoted greater production of the cauliflower.

Therefore, it is evidenced the importance of the presence of $B$ in the nutrient solution to increase its uptake (Table 3) and favor the growth by increasing leaf area, reflecting on crop productivity.

Similar results on the effects of B on cauliflower productivity were reported by Kumar et al. (2002) and Khadka et al. (2005).

Cauliflower plants under micronutrient deficiency depreciate the nutritional value of the inflorescence as they presented low $B$ content $\left(23 \mathrm{~g} \mathrm{~kg}^{-1}\right)$, which is value quite below that of plants under nutrient sufficiency $\left(42 \mathrm{~g} \mathrm{~kg}^{-1}\right)$, which presented high yield. As the daily recommendation of boron for human consumption is $10 \mathrm{mg}$ (Naghii et al., 2011), this shows that even with the low content of $23 \mathrm{~g} \mathrm{~kg}^{-1}$, the nutritional requirement is possible to be achieved.

Overall, it has been observed that cabbage plants are more sensitive to $B$ deficiency than cauliflower. This is because the levels of $B$ in the leaves lower than $27 \mathrm{~g} \mathrm{~kg}^{-1}$ has already induced low dry mass production of cabbage plants whereas in the cauliflower plants this occurred only with greater levels of $B$ in the leaves, which is lower than $43 \mathrm{~g} \mathrm{~kg}^{-1}$.

\section{Experiments III and IV Cabbage}

Leaf spraying of the solution with $B$ and lack of the nutrient over 30 days increased the vegetative variables, reaching maximum values equal to 5117.60 and $4409.26 \mathrm{~cm}^{2}$ for leaf area; 23.07 and $23.20 \mathrm{~cm}$ for height; 22 and 21 for number of leaves, and 8.95 and $11.69 \mathrm{~mm}$ for stem diameter.

For the dry mass of the leaves, and of the roots (Figures $1 \mathrm{a}$ and $\mathrm{b}$ ), the largest increments (48.20 and $5.45 \mathrm{~g}$ per plant, respectively) were reached at 30 days with boron application. In the solution without boron, the increments were of 43.60 and $5.27 \mathrm{~g}$ per plant for dry mass of the leaves and root, respectively, also at 30 days.

An increase was verified in the $B$ content in the leaves in the treatment that received the foliar fertilization, when compared to the leaves of the control treatment (Figure 1c). The B content in the leaves reached a peak of $89.10 \mathrm{mg} \mathrm{kg}^{-1}$ three hours after the micronutrient spraying. The control plants showed the same behavior in the leaves reaching a maximum content of $45.80 \mathrm{mg} \mathrm{kg}^{-1}$ three hours after the application of the solution.

The maximum boron accumulation in the leaves was $1.10 \mathrm{mg}$ per plant at 30 days after leaf spraying of the micronutrient. The absorption of $\mathrm{B}$ by the leaves of the cabbage is slow, reaching an uptake of $50 \%$ of the $B$ applied in the period of 15 days (Figure 1d). Thus, it can be inferred that if rainfall occurs before 15 days after application of boron, it could compromise the efficiency of foliar fertilization, because $50 \%$ of the nutrient absorption occurred only after 15 days after its application.

It was found an increase in boron accumulation in the leaves of the plants that did not receive the solution. That means that it may contain traces of boron in the fertilizers used in the nutrient solution without boron and also because the irrigation water had supplied $\left(6.22 \mathrm{\mu g} \mathrm{L}^{-1} \mathrm{~B}\right)$ some of the boron to the plants 
(a)

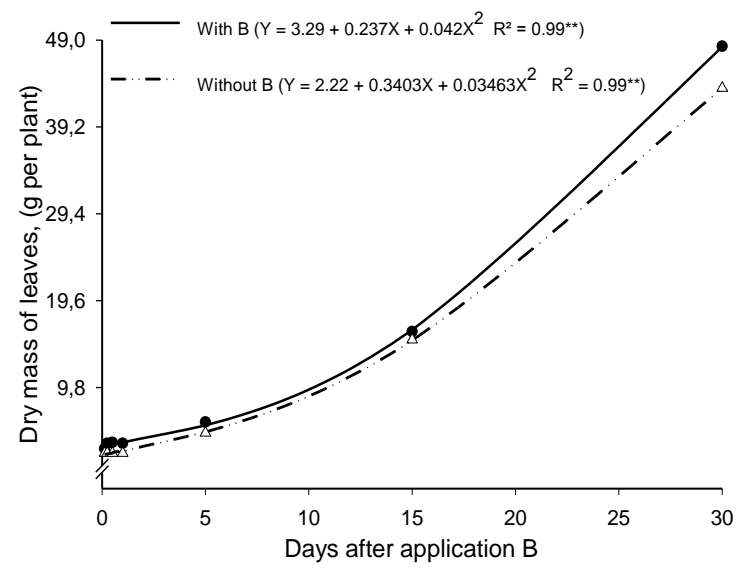

a (c)

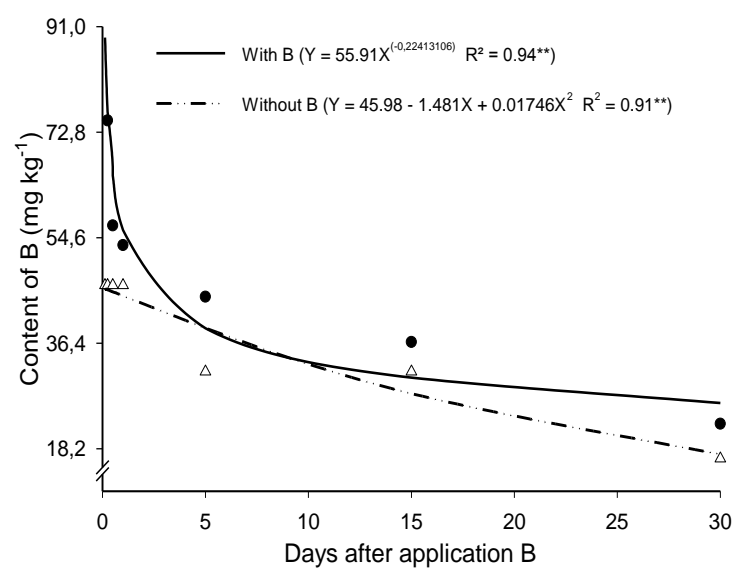

(b)

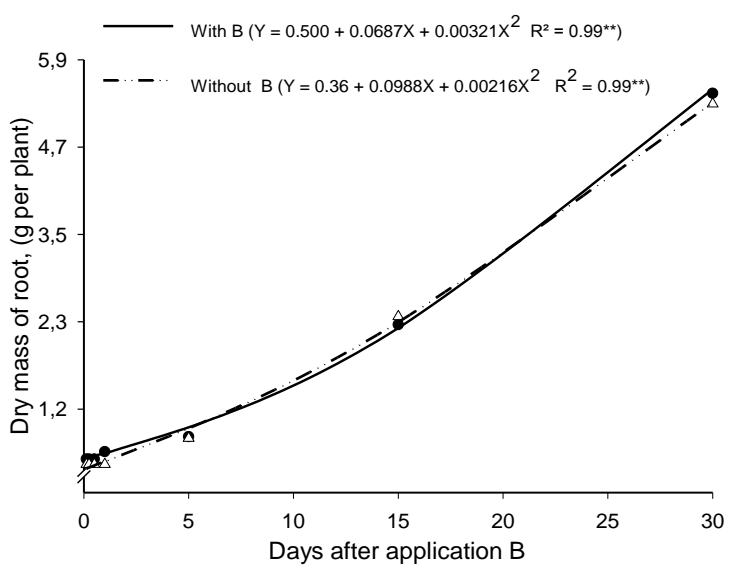

(d)

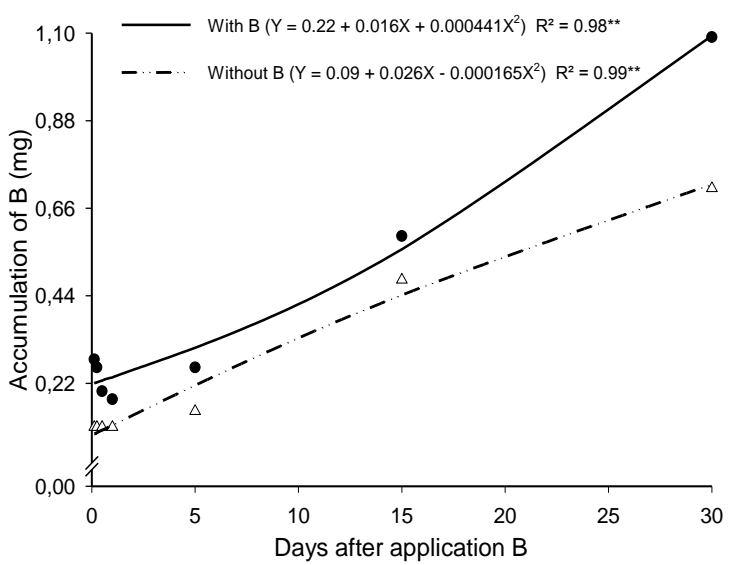

Figure 1 - Dry mass of leaves (a) and root (b), content (c) and accumulation of $B(d)$ in leaves as a function of time after application of boron solution via leaf at $0.12(3 \mathrm{~h}) ; 0.25(6 \mathrm{~h}) ; 0.5$ (12 h); 1; 5; 15 and 30 days after application, in "Astrus" cabbage plants at 53 days after transplanting.

Boron absorption rate by cabbage leaves was slow. This may have occurred due to the high content of wax of the leaves. This is because the nutrient absorption rate by the leaves depends mainly on the thickness of the cuticle and on the wax layer (Kerbauy, 2004), and recent studies have shown that cuticular waxes are actually the real barrier to the entry of solutes into leaf tissue (Riederer \& Schreiber, 2001).

\section{Cauliflower}

Foliar spraying of the solution with B and lack of the nutrient over 30 days increased the vegetative variables, reaching maximum values equal to 5627.98 and $5035.41 \mathrm{~cm}^{2} ; 40.98$ and $40.45 \mathrm{~cm} ; 19$ and 21; 13.46 and $10.65 \mathrm{~mm}$, for leaf area; height, number of leaves and stem diameter, respectively.

For the dry mass of the leaves and root (Figure $2 \mathrm{a}$; b) the highest increments (57.56 and 20.48 $\mathrm{g}$ per plant, respectively) were reached at 30 days with boron application. The lack of boron achieved increments of 50.33 and $7.09 \mathrm{~g}$ per plant for dry mass of leaves and root, respectively, also at 30 days.

It can be observed that at 30 days after $B$ leaf spraying, a higher production of dry mass of cauliflower root was achieved in relation to the plant without application of the micronutrient (Figure 2b). This indicates that because $\mathrm{B}$ plays the role of transporting carbohydrates from the leaf to the root (Prado, 2008) promoted greater growth of the plant root system.

An increase in the B content in the leaves in the treatment that received the foliar fertilization was found when compared to the leaves of the control treatment (Figure 2c). The B content in the leaves of cabbage that received boron fertilization reached a maximum of $92.2 \mathrm{mg} \mathrm{kg}^{-1}$ three hours after application. The leaves that did not receive micronutrient application had a maximum content of $39.7 \mathrm{mg} \mathrm{kg}^{-1}$ three hours after application 
(a)

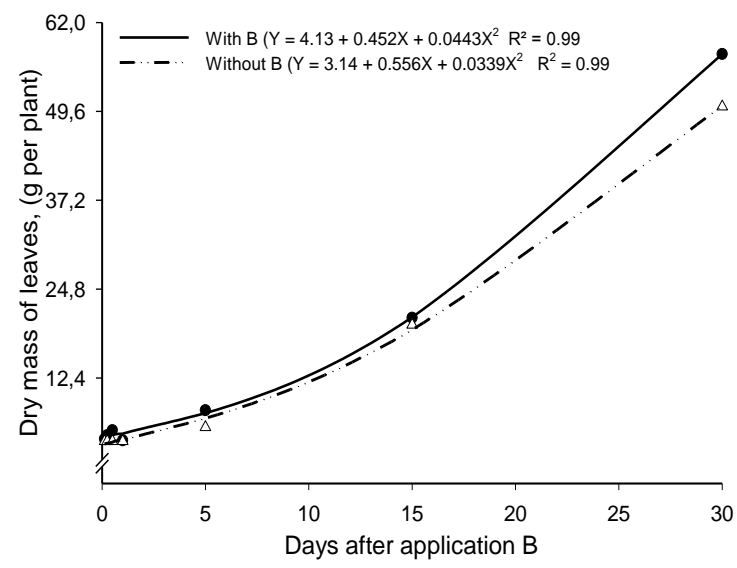

(c)

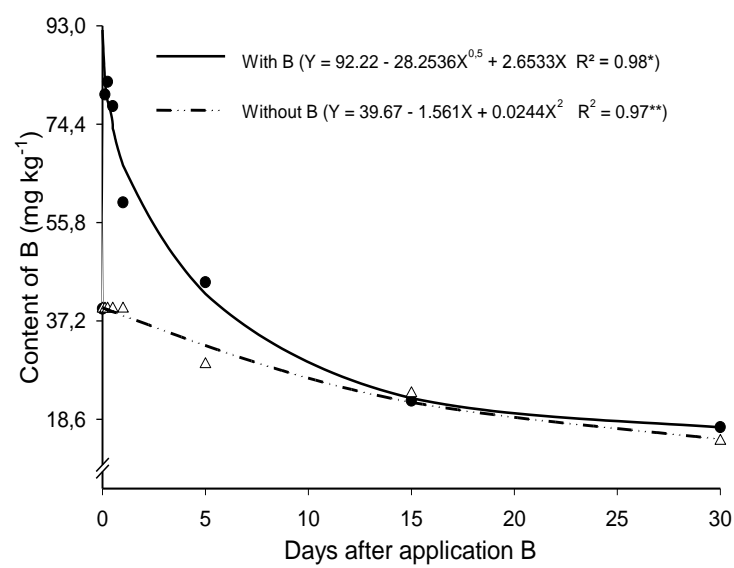

(b)

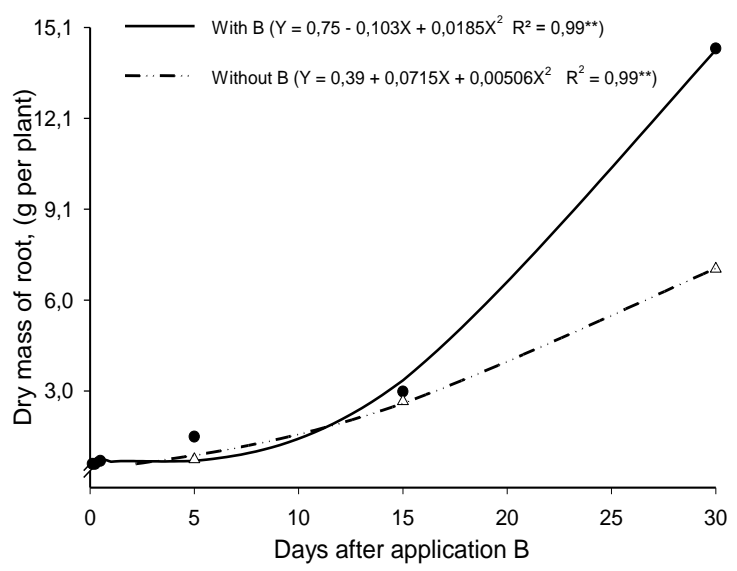

(d)

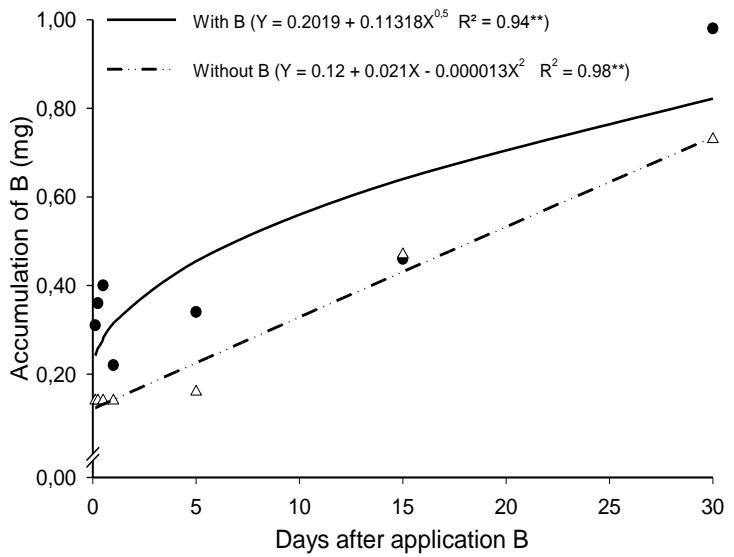

Figure 2 - Dry mass of leaves (a) and root (b), content (c) and accumulation of B (d) in leaves as a function of time after application of boron solution via leaves at $0.12(3 \mathrm{~h}) ; 0.25(6 \mathrm{~h}) ; 0.5(12 \mathrm{~h}) ; 1 ; 5 ; 15$ and 30 days after application, in 'Verona' cauliflower plants, 50 days after transplanting.

The maximum accumulation of boron in the leaves was $0.82 \mathrm{mg}$ per plant, at 30 days after application of the solution. Boron is absorbed by the cauliflower leaves faster than by the cabbage leaves, absorbing $50 \%$ of the B applied over a period of approximately three days and 12 hours (Figure 2d). Thus, it can be inferred that if rainfall occurs after four days after its application, it will not compromise the efficiency of foliar fertilization, since $50 \%$ of the nutrient absorption by the plant has already occurred.

The absorption rate of boron by cauliflower leaves was faster (three days and 12 hours after application of the solution) when compared to cabbage (15 days after application of the solution). This may have occurred due to the lower content of wax of the leaves.

\section{Conclusions}

The effect caused by the lack of boron was evident in the final stage of growth of the vegetables, resulting in a decrease in productivity. However, cabbage was more sensitive to nutrient deficiency than the cauliflower.

Boron is slowly accumulated by 'Astrus' cabbage leaves, absorbing $50 \%$ of the applied $\mathrm{B}$, about 15 days after its application and 'Verona' cauliflower, at three days and 12 hours after boron application.

\section{References}

Alam MN (2007) Effect of boron levels on growth and yield of cabbage in calcareous soils of Bangladesh. Research Journal of Agriculture and Biological Sciences 3(6):858-865 .

Cakmak I, Römheld V (1997) Boron deficiency-induced impairments of celular functions in plants. Plant and Soil 193(1-2):71-83.

Francisco, M; Tortosa, M; Martínez-Ballesta, MC; Velasco, P; Moreno, DA (2017) Nutritional and phytochemical value of Brassica crops from the agrifood perspective. Annals Applied Biology, 170:273285, Out. 2017. 
Hoagland DR, Arnon DI (1950) The water culture method for growing plants without soils, California Agricultural Experimental Station. 347 p.

Kerbauy GB (2004) Fisiologia Vegetal, Guanabara Koogan. 452 p.

Khadka YG, Rai SK, Raut S (2005) Effect of boron on cauliflower production. Nepal Journal of Science and Technology 6(1):103-108.

Kumar S, Chaudhury DR, Kumar S (2002) Effect of FYM, molybdenum and boron application on yield attributes and yields of cauliflower. Crop Research Hisar 24(3):494-496.

Marschner H (1995) Mineral nutrition of higher plants. 2nd ed. New York: Academic Press, p.379-396.

Naghii MR, Mofid M, Asgari AR, Hedayati M, Daneshpour MS (2011) Comparative effects of daily and weekly boron supplementation on plasma steroid hormones and proinflammatory cytokines. Journal of Trace Elements in Medicine and Biology 25(1):54-58.

Ningawale DK, Singh R, Bose US, Gurjar PS, Anchal Sharma, Gautam US (2016) Effect of boron and molybdenum on growth, yield and quality of cauliflower (Brassica oleracea var botrytis) cv. Snowball 16. Indian Journal of Agricultural Sciences 86(6):825-829.

Pandey AN, Verma P (2017) Boron deficiency and toxicity and their tolerance in plants: a review. Journal of Global Biosciences 6(4):4958-4965.

Peryea FJ (2005) Sample washing procedures influence mineral element concentrations in zinc-sprayed apple leaves. Comunications in Soil Science and Plant Analysis 36(19-20):2923-2931.
Pizetta LC, Ferreira ME, Cruz, MCP, Barbosa JC (2005) Resposta de brócolis, couve-flor e repolho à adubação com boro em solo arenoso. Horticultura Brasileira, Brasília 23(1):51-56.

Prado RM (2008) Nutrição de plantas, UNESP. 407 p.

Prasad VM, Yadav D (2003) Effect of foliar application of boron and molybdenum on the growth and yield of cauliflower (Brassica oleracea var. botrytis) cv. Snowball-16. New Agriculturist 14(1/2):121-122.

Riederer M, Schreiber L (2001) Protecting against water loss: analysis of the barrier properties of plant cuticles. Journal of Experimental Botany 52(363):20232032.

SAEG - Sistema de análises estatísticas e genéticas (2000) UNIVERSIDADE FEDERAL DE VIÇOSA UFV. Versão 8.0, UFV. 142 p.

Silva KS, Santos ECM, Benett CGS, Laranjeira LT, Eberhardt Neto E, Costa E (2012) Produtividade e desenvolvimento de cultivares de repolho em função de doses de boro. Horticultura Brasileira 30(3):520525 .

Tedesco MJ, Gianello C, Bissani CA, Bohen $\mathrm{H}$, Volkweiss S (1995) Análise de solo, planta e outros materiais. Porto Alegre: Departamento de Solo. Faculdade de Agronomia. Universidade do Rio Grande do Sul. $174 \mathrm{p}$. 